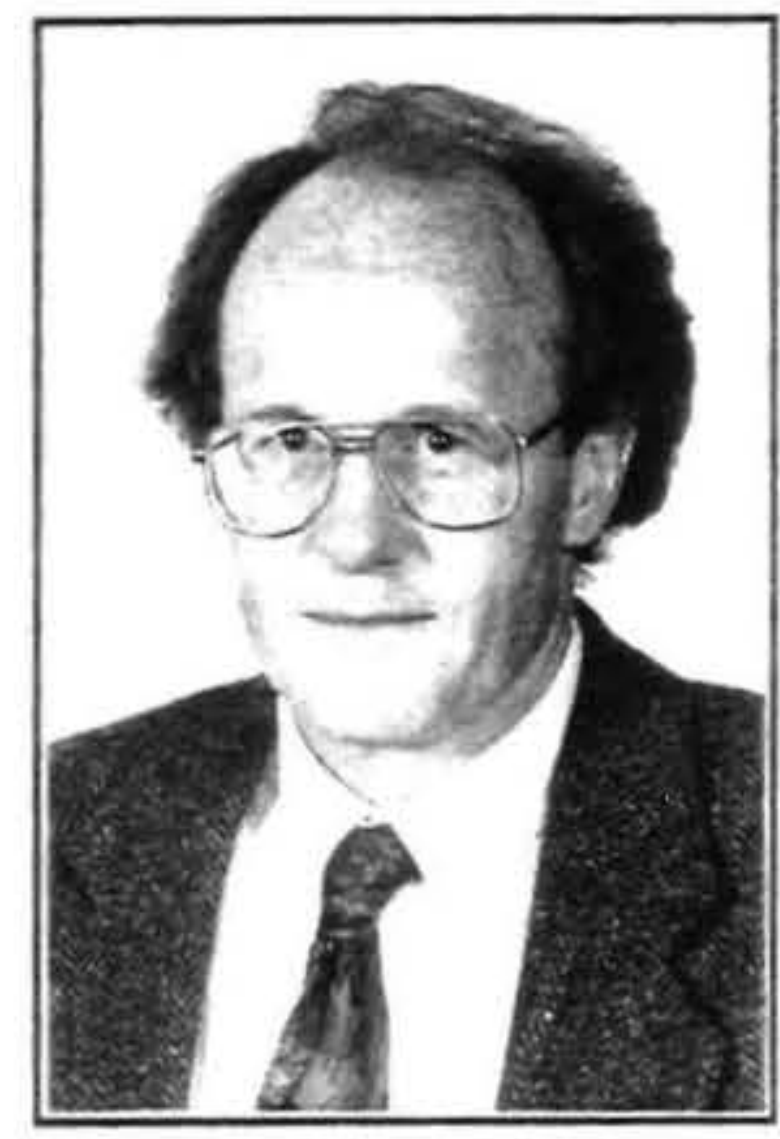

\title{
WORK AND RESIDENCE IN URBAN LABOUR MARKETS 1
}

\author{
Philip S. Morrison \\ Victoria University of Wellington
}

\begin{abstract}
This paper explores the relationship between the labour market and the spatial organisation of urban areas. A disintegration thesis' is introduced which argues that the separation of social groups by residence reflects the occupational divisions in the local labour force. The redistribution of paid work which accompanies structural change in the labour market is therefore expected to be reflected in changes to the spatial organisation of employment. Primary mechanisms are the decentralisation of employment opportunities from the city centre, reductions in the length of the journey to work and the closer geographic clustering of home and work. The argument is illustrated with data from the Wellington region.
\end{abstract}

Urban areas are simply ways of spatially organising labour markets. As such they are geographic reflections of the institutions which allow capital and labour to generate labour contracts. It follows that as the labour market changes so too will the human geography of the city.

Behind this simple idea there is of course a complex array of contextual and intermediate phenomena which can blur the connections between the labour market as an institution and the urban area in its physical and functional form. Much of this detail must be passed over in order to focus on the main argument.

We begin with the working proposition that the (residential) geography of socio-economic groups is a spatial reflection of three factors: the local division of labour, the location of industry and the geography of the housing market. We take it as a logical consequence that changes in the organisation and allocation of work operate through the industrial, office, land and housing markets to affect change in the spatial organisation of labour market. By extension, new divisions within the workplace that accompany structural change get translated into employment, residential and journey to work patterns.

While this paper is limited to establishing the points of connection between the local labour market and the social geography of the city, the broader aim is to raise questions about the urban labour implications of structural change, that is how changes in the mix of industries and occupations in a city influence the spatial organisation of social classes and the spatial distribution of real income.

The relationship between the social geography of the city and the labour market remains remarkably undeveloped in writing both on the city and the labour market. Dahms, writing on Auckland 25 years ago, noted how the 'classical' models virtually ignored the effect of workplace-residence linkages upon the form of the city (Dahms, 1971: 130). More recently Harvey tried to force a debate over the connections. Instead of regarding residential differentiation as the passive product of a preference system based on social relationships, he argued that we have to see it as an integral mediating influence in the process whereby class relationships and social differentiation are produced and sustained. He goes on to make the point that residential groupings which reproduce labour power to meet the needs of an existing division of labour may also form a distinctive grouping from the standpoint of consumption and that such a coalescence gives residential areas their homogeneous character (Harvey, 1985: 124). Contemporary developments of this argument are long overdue:

The paper is in four sections. The first advances the 'disintegration of the city' thesis. This is followed by a brief summary of previous work on the residential separation of occupational groups and a presentation of the Wellington evidence. In the third section similar evidence is sought for occupational segregation by workplace. Attention turns in the fourth section to the way in which the geography of the labour and housing markets is linked through the journey to work matrix. Then we briefly refer to the possible impacts of structural change.

\section{The disintegration of the city}

As we move towards the end of this century there is increasing concern that societies, rather than becoming more cohesive, are in fact fragmenting and segmenting along a number of dimensions. The discussion goes under various terms: social polarisation (e.g. Pinch, 1993; Hamneth, 1994), uneven development (e.g. Stubbs and 
Barnett, 1992), marginalisation (e.g. Winchester and White, 1988), fragmentation (Thorns, 1992) and quartered cities (Marcuse, 1989) to name five. Increasingly these trends are being linked to the redesign of the welfare state and associated privatisation (LeGrand and Robinson, 1984). This link is now apparent in a number of areas in New Zealand including health (Barnett, 1987, 1993 ), education (Lauder et al, 1994), housing (Morrison, 1995) and of course the labour market (see for example the papers by Dixon, Easton, Manuka and Jackson in this volume).

The post war period saw an accelerated suburbanisation of the population in New Zealand cities. Increasing affluence and the rapidly expanding supply of new land which the motor car and highway building allowed increased the scope for the further physical separation of social classes by residential location within the urban area. This process of housing market segmentation and the spatial separation that accompanied it has been fueled by the transformation in the nature and organisation of paid work itself. It has also been encouraged by the marked decentralisation of employment which began well before the second world war and accelerated in the post war period. As pressures on labour costs and land rents rose with the expansion of the central city it became a rational strategy for many enterprises to relocate close to the growing labour pools in the suburbs. This was facilitated by new organisational forms and technological developments which allowed the physical separation of functions within the firm (see Stanback, 1991). The net effect for many workers was to bring work closer to the residence.

This paper argues that one of the net effects of suburbanisation of employment has been the creation of clusters of work-residence areas which are increasingly differentiated by occupation and its associated income, status and power differences. Socially and well as spatially this process constitutes a gradual fragmentation or separation of economic and social groups within the city. The net result is a joint pattern of work and residential separation which, although continuing to involve mass population movements each day, is doing so within increasingly separated areas of the metropolis. It is this idea which forms the basis of the 'dis-integration thesis'.

The result of this spatial disintegration is not any reduction in the economic interdependence and inter-industry integration of the city but rather a diminishing social integration of labour which, when combined with the marginalising effects of the decline in the welfare state and privatisation, is leading to the creation of activity sub-centres in which particular work, family, income and life-style characteristics are becoming increasingly separated from other subcentres. The significance of these developments lie in the fact that increasingly more and more social support decisions are being left to these geographically defined 'communities'. The increasing isolation implied in the increased social and spatial clustering increases rather than diminishes the likelihood that the relatively disadvantaged will be further marginalised by a disinterested affluent majority.

\section{Residential separation by occupation}

The spatial separation of occupations has been one of the most enduring features of the urban labour market. In early cities members of distinct occupations lived and worked in separate districts or quarters (e.g. Vance, 1971). The separation of work and residence which suburbanisation fostered did not do away with occupational separation at home or work. Those involved in assembly work, retailing sales and education for example continued to work at quite separate locations in the city as a result of specialisation of their industry's land use. Separation of occupation by residence however reflected not the physical character of the work but the income, wealth and social status differences which the labour market accorded the different occupations.

The persistence of residential segregation by occupation has been demonstrated in several previous studies of the city (Schnore, 1965; Duncan and Duncan, 1955; Wheeler,1968). Such evidence does not appear to have been assembled for the New Zealand city with the interesting exceptions of Jones (1972) and Dahms (1973). This lack of commentary is surprising given the fact that the relationship between occupation and residence in contemporary New Zealand is remarkably systematic. ${ }^{2}$

The degree to which occupations separate into distinct residential locations is apparent from the scatterplot matrix or SPLOM, in figure 1. Together with the accompanying correlation coefficients the scatters show how the skill proximity of adjacent major occupations are mirrored residentially. ${ }^{3}$ The scatters are linear, positive and reasonably strong immediately off the diagonal. The further the eye moves away from the diagonal, the weaker (more scattered) and the more non-linear the relationships become. Then, as one confronts the interactions of increasingly different occupations, so the non-linearity reduces and in the far corners of the SPLOM the scatters themselves become negative. These data confirm the common observation that people in like occupations live in proximity and those who are different live apart; the greater the skill difference between any two occupational groups (and hence their education and training) the greater their degree of residential separation.

This generalisation about occupational separation does not deny the presence of mixing of course. High levels of avoidence by residence tends to be limited to the extremes of the occupational distribution: Admin/managers vs Elementary occupations for example. The desire for residential proximity with others of similar occupational status produces clearer patterns of spatial association than does the desire for avoidence: the correlation coefficients get systematically weaker as more 'distant' occupations are compared. ${ }^{4}$

\section{Spatial separation of occupations at work}

The next question our disintegration thesis leads us to ask 
Figure 1. The spatial correlation of eight major occupational groups in the Wellington urban area, 1991. A scatterplot matrix (SPLOM)

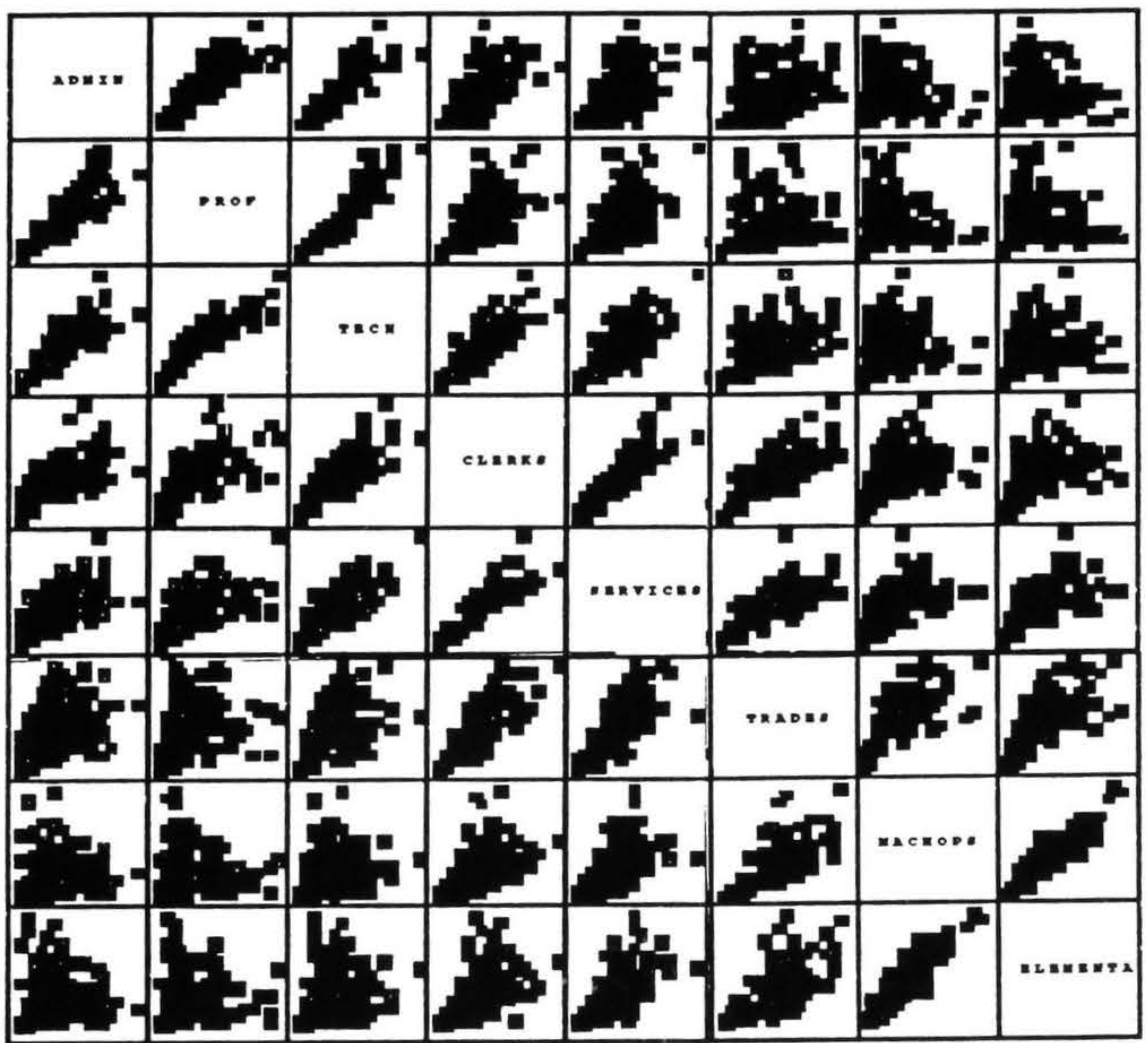

Pearson Correlation Coefficients

\begin{tabular}{|l|l|l|l|l|l|l|l|}
\hline & Admin & Prof & Tech & Clerical & Service & Trades & $\begin{array}{l}\text { Mach } \\
\text { Ops }\end{array}$ \\
\hline Admin & & & & & & & \\
\hline Prof & .869 & & & & & & \\
\hline Tech & .876 & .917 & & & & & \\
\hline Clerical & .675 & .595 & .797 & & & & \\
\hline Service & .571 & .523 & .736 & .878 & & & \\
\hline Trades & .370 & .169 & .447 & .792 & .764 & & \\
\hline Mach Ops & -.087 & -.159 & .054 & .474 & .543 & .739 & \\
\hline Elem. & -.027 & -.037 & .157 & .512 & .637 & .695 & .927 \\
\hline
\end{tabular}

Source: Statistics New Zealand. SUPERMAP2

is whether the level and direction of separation we see in the residential consumption pattems of different occupations is also reflected in the spatial pattems of work. There is considerably less examination of this issue. Analysis of the relationship between occupational stratification and residential distribution by the Duncans in Chicago for example used occupation as a measure of socio-economic status but there was no suggestion that the spatial structure of jobs in Chicago in the 1950 s might be separated nor that they might be related to the residential distribution of occupational groups (Duncan and Duncan, 1955).

Neither was the link considered by Wheeler in his study of Pittsburgh (Wheeler, 1968). The hypothesis Wheeler posits is essentially the same as the Duncans, namely that, "groups with similar occupational status will have similar 
patterns of residential location" and his findings are similar (Ibid: 311 ). However, Wheeler does add one idea that foreshadows ours, namely that, "occupational status levels should have relatively distinct residential locations, which in turn will be associated with a pattern of employment location" (Ibid: 312).

Wheeler did not actually pursue this last point in his paper and no subsequent studies appear to explore the connection between increasing spatial divisions of labour within cities and their pattem of residential separation. The question has been anticipated however from both the labour demand and supply sides in connection with the decentralisation of jobs.

The decentralisation of manufacturing, retailing and offices had been going on for considerable time as Michelle White's summary of the declining density gradients for United States cities shows, Table 1. Muller noted how this decentralisation of employment challenged the stereotypical view of the residential suburb.

Because of growing suburban dominance in American metropolitan employment activity the lingering view of a dominant central city with dependent suburbs must be discarded. With a majority of metropolitan residents now working in the outer city, the notion of 'bedroom suburbia' has become obsolete. Journey to work patterns reflect this and have shifted decisively since 1960; for example in the 15 largest SMSAs the number of workers who both live and work in the suburbs has increased by at least three million (about 50 percent) and the number of reverse commuters has doubled to just under ten percent of the total work trips in these regions (Muller, 1976: 32).

Guest recognised even more explicitly the way much of 'suburbia' had become a mix of workplaces and residences and that the two "are not very segregated from one another" (Guest, 1976: 63). But more importantly Guest went on to point out that, "the overlap in residential and workforce population in most suburban communities suggests that many persons may live and work in the same community (Ibid, p66). Moreover, there is a high correlation between most community workforce and residential characteristics (Ibid, p 71) suggesting that "many suburban residents live their lives within geographically seg-

Table 1. Density gradients for a sample of eighteen United States metropolitan areas, 1948-1980

19481954195819631970197219771980

\begin{tabular}{lrrrrrrr}
\hline Population & .58 & .47 & .42 & .38 & .29 & & \\
Manufacturing & .68 & .55 & .48 & .42 & & .34 & .32 \\
Retailing & .88 & .75 & .59 & .44 & & .35 & .30 \\
Services & .97 & .81 & .66 & .53 & & .41 & .38
\end{tabular}

Sources: M.J. White (1994:142) and citations mented parts of the metropolis" (Ibid, p 79, my emphasis).

More recently, O'Conner observed for Melbourne how,

increasing numbers of workers have been able to pair a suburban job and a suburban house, so reducing the need to travel to the central region. It is this set of links that are now critical to the way Melbourne operates as they provide an alternative foci throughout the suburbs. These work locations are reinforced by regional shopping centres and a wide range of services and activities that reduce the importance of the CBD and the central region in the daily life of the majority of Melboume residents (O'Conner, 1994: 15). ${ }^{5}$

\section{Local evidence}

Decentralisation of jobs in Wellington has not proceeded rapidly nor to the extent apparent in large Australian and United States centres or even Auckland (see Dahms, 1973). Partly as a result, the evidence for spatial separation of work sites by occupation in Wellington is is rather weak as is apparent from figure 2. This SPLOM is constructed by plotting the logarithm of the counts of each occupation at their work place. Even though we have (log) transformed the distribution to give smaller work sites greater representation, the results show much closer spatial integration of occupations at the workplace than at their residence.

On first acquaintance the spatial separation of occupational groups at work has more to do with the evolving patterns of land use and hence the physical functioning of the city. However the organisation of work itself and who needs to work with whom in different settings is likely to have an increasing impact on the physical juxtaposition of workplaces not just in terms of horizontal space but vertical space as well. Only the former can be explored here.

Figure 2 shows that the most marked spatial separation of workplaces occurs between Professionals and Machine Operators (Assembly and associated staff). This is mainly a reflection of the landuse requirements of an office vs factory based occupational group. The particular communication and market requirements of the Professionals encourage clustering within the central city itself compared to the demand for flat sites and lower suburban rentals which have encouraged the decentralisation of industry and its workforce.

The need for technical, clerical and service support staff in the operation of many professional practices ensures at least under present technology that staff will share common work locations (however see Holti and Stem, 1986 and Ceramalus, 1994). The broad set of Administrative occupations also require a similar support staff but interestingly not the physical proximity of the Professionals. Unfortunately space limitations of this volume do not allow us to show the associated maps which are easily 
Figure 2. Scatterplot matrix showing the correlation between the workplace distribution of occupations in the Wellington urban area, 1991

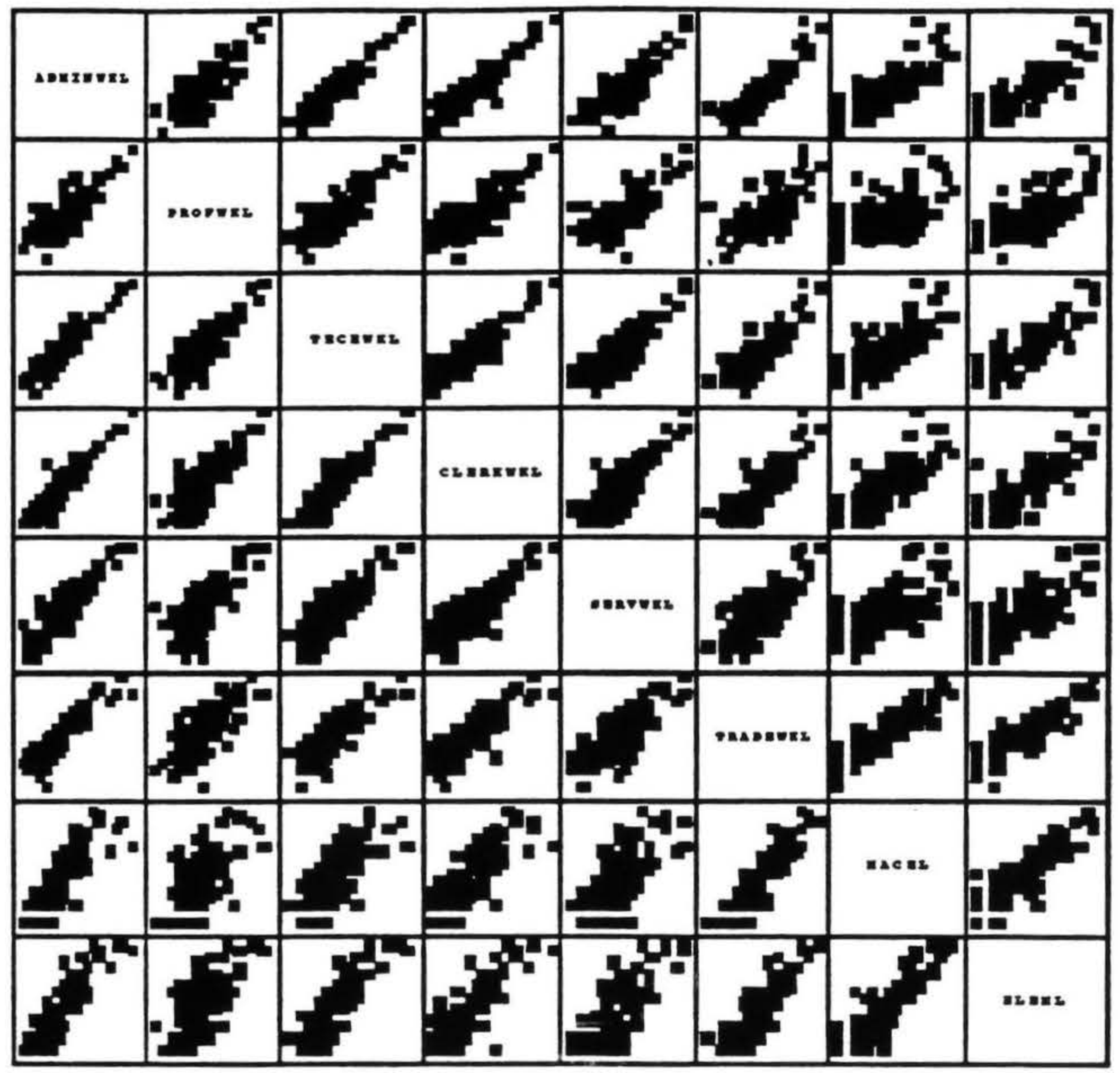

Pearson Correlation Coefficients

\begin{tabular}{|l|l|l|l|l|l|l|l|}
\hline Logarithms & Admin & Prof & Tech & Clerical & Service & Trades & $\begin{array}{l}\text { Mach } \\
\text { Ops }\end{array}$ \\
\hline Admin & & & & & & & \\
\hline Prof & .790 & & & & & & \\
\hline Tech & .941 & .815 & & & & & \\
\hline Clerical & .938 & .800 & .916 & & & & \\
\hline Service & .863 & .768 & .845 & .847 & & & \\
\hline Trades & .908 & .675 & .862 & .849 & .772 & & \\
\hline Mach Ops & .801 & .529 & .723 & .744 & .631 & .873 & \\
\hline Elem. & .801 & .647 & .827 & .831 & .736 & .869 & .877 \\
\hline
\end{tabular}

Source: Statistics New Zealand: SUPERMAP2

produced from this data base.

The evidence in figure 2 is suggestive. However the patterns invite considerably more sensitive research designs than used here, particularly if one is to explore the changing pattern of face to face communication between occupational groups. What is clear in general if not specific terms however is that while there is a physical working proximity among most occupations some occu- pations are clearly more likely to be in daily face to face contact than others. ${ }^{6}$

The third dimension in any exploration of the spatial patterns of residence and work among occupations is the nature of the correlation between the work and residence locations themselves. In particular what evidence is there for the existence of growing clusters of residence and work patterns which differ from one occupational group to 
another? Addressing this question requires turning to the journey to work itself.

\section{Journey to work}

While systematic inquiry into urban travel to work patterns per se go back at least 40 years, our present concern differ in a number of important respects. Most of the writing on travel to work after World War Two focussed on the dysfunctional, notably on the lengthening of the journey to work and their effect on separated family members (e.g. Carroll, 1952; Schnore, 1965; McGee, 1969 esp. p153) and the wider costs to the community through congestion and road expenditure (see Evans, 1985). These discussions were held under the shadow of potentially ever lengthening journeys. It would have surprised such researchers to learn that journey to work times would remain fairly constant for over forty years largely as a result of the decentralisation of employment and the increased speed of travel due to the greater access to cars and the associated decline in the use of much slower public transport (Newman and Kenworthy, 1989; Gordon, Kumar and Richardson, 1989). ${ }^{7}$

In exploring the implications of decentralisation of employment sites two concepts are useful - the labour shed and the employment field (Vance, 1960). The labour shed is the geographical catchment area from which any given plant or offices draws its labour and the employment field describes the set of job locations open to those residing in a given area unit. Just as one can compare the characteristics of labour sheds, so one can compare employment fields: their range, concentration and distance.

\section{Properties of the journey to work}

The basic properties of labour sheds were explored quite early on by Carroll (1952) who found considerable support for a gradient pattern of worker residences by distance from the workplace and that the fundamental principal of least effort. Support for living close to one's work was found by Schnore in his study of six industrial plants in Flint Michigan (Schnore, 1965: 333ff). The tendency for the workplace to draw a decreasing proportion of its workforce from distances further away is now firmly established and contemporary graphs of these positively skewed distance to work distributions may be found in Wachs et al (1993). The majority of commuters travel only short distances with 5-7 kilometres being the median in a wide variety of cities in the United States, Australia and New Zealand.

Although the general shape of the distance to work distribution is well established their parameters are known to vary considerably by worker type, size of urban area and a variety of other factors. Schnore was able show that labour sheds were far from exclusive and that, "each plant draws workers from each of the five distance zones in accordance with the number of persons it employs" (Schnore 1965: 334). The measure used was the ratio of workers in that plant to the resident population. Schnore also noted a tendency for newer and more rapidly expanding industrial installations to draw workers from a wider area (also see Liepmann, 1944). A similar relationship between new establishments and longer distance commuters was also identified by Wachs et al (1993).

Rees and Schultz (1970) show however that such employees have to be attracted from further away by higher wages. In 10 of the 12 occupations studied by Rees and Schultz wages were positively related to the log distance of the commute suggesting that costs of commuting are a nonlinear function of distance (Rees and Shultz, 1970: 173; also see Goldner, 1955). Typically it is the higher paid on the site who travel the longer distances.

That shorter distances are travelled by lower paid, elementary workers is also well documented (see Duncan and Duncan, 1957). However there is an important distinction between distance and time. The same authors found for example that, "inspite of the fact that physical separation of residents and workplaces varied directly with the occupation of the workers, there was very little difference between high and low status workers in the time expended on the journey to work (Duncan 1956:57 as cited in Dahms 1971:132). ${ }^{8}$

An important feature of these occupational differences is their correlation with gender. Rees and Shultz observed a tendency for women to travel shorter distances to work and this has been a subject of considerable study in recent years (see for example Blumen and Kellerman, 1990 and Hanson and Pratt, 1991). The close association between gender and occupation renders this gender bias of some significance partly because it forces us to recognise the constraints which household structures, life cycle stage and domestic relationships impose on the properties of labour sheds and employment fields (see JohnstonAnumonwo, 1992).

\section{The journey to work matrix}

Early empirical investigations of the joumey to work viewed the task primarily as defining boundaries of commuting areas and delimiting local labour markets (see Berry and Horton, 1970; Smart, 1974; Dahms, 1973). While this cartographic approach is necessary in defining the extent of urban labour markets, it is not the most helpful way of thinking thinking through issues in the disintegration thesis. For this task the journey to work matrix itself offers greater insight. The quinquennial population census asks the gainfully employed to give the name and location of their employer which is then paired with their place of usual residence and this is sufficient information for the generation of the journey to work matrix.

The journey to work matrix is an $\mathrm{i} x \mathrm{j}$ table whose cells contain counts of the number of gainfully employed who commute from their place of residence $i$ to their place of work $\mathrm{j}$, hence Eij. In order to construct such a matrix the 


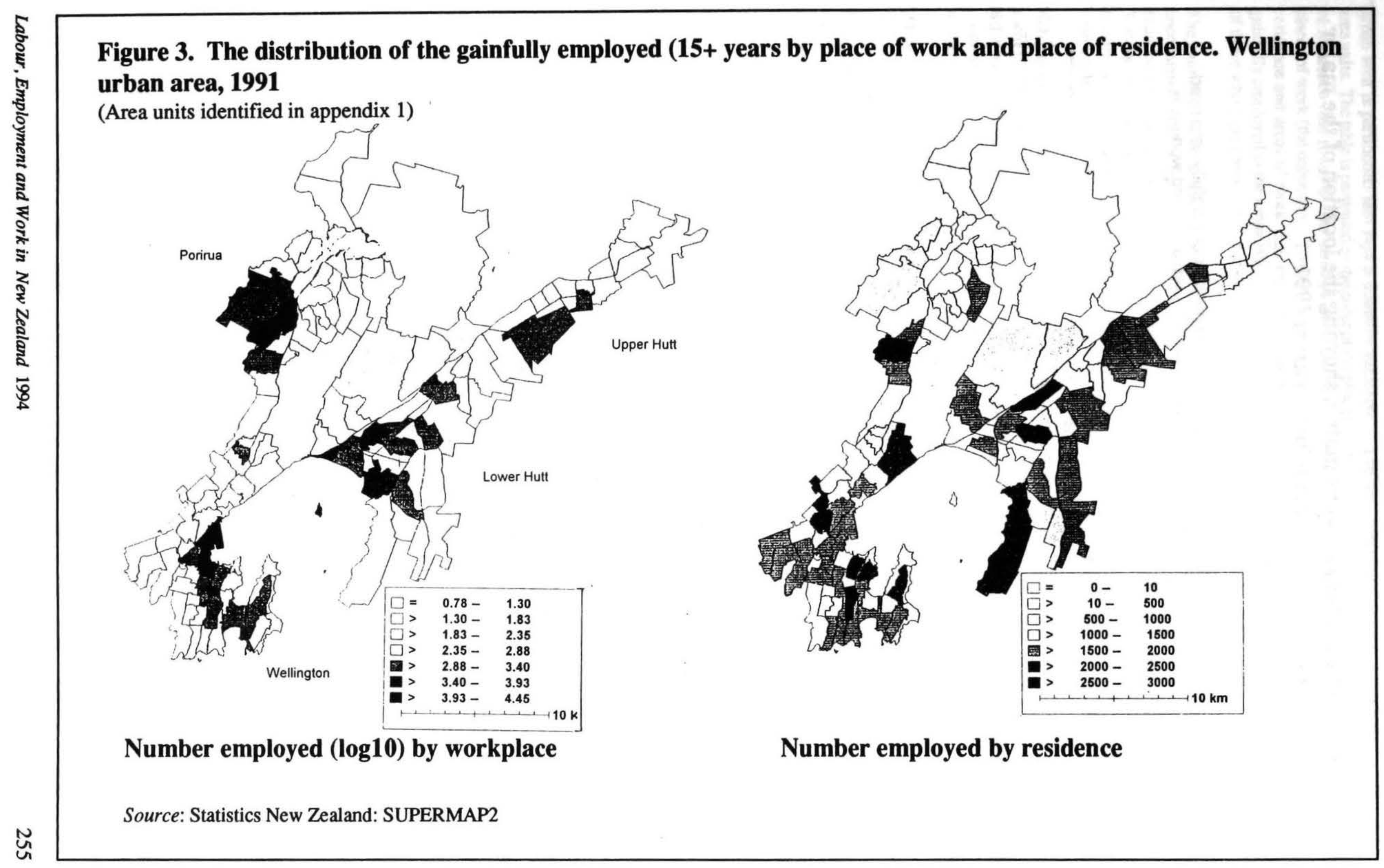


Figure 4. The journey to work matrix showing the location of the major employment centres. Wellington urban area, 1991

The count in each cell.represents the number of gainfully employed in March 1991 ( $\geqslant 15$ years) who lived in area unit $i$ and worked in area unit $\mathrm{j} . \mathrm{i}=\mathrm{j}=1,2, \ldots 136$

Workplace

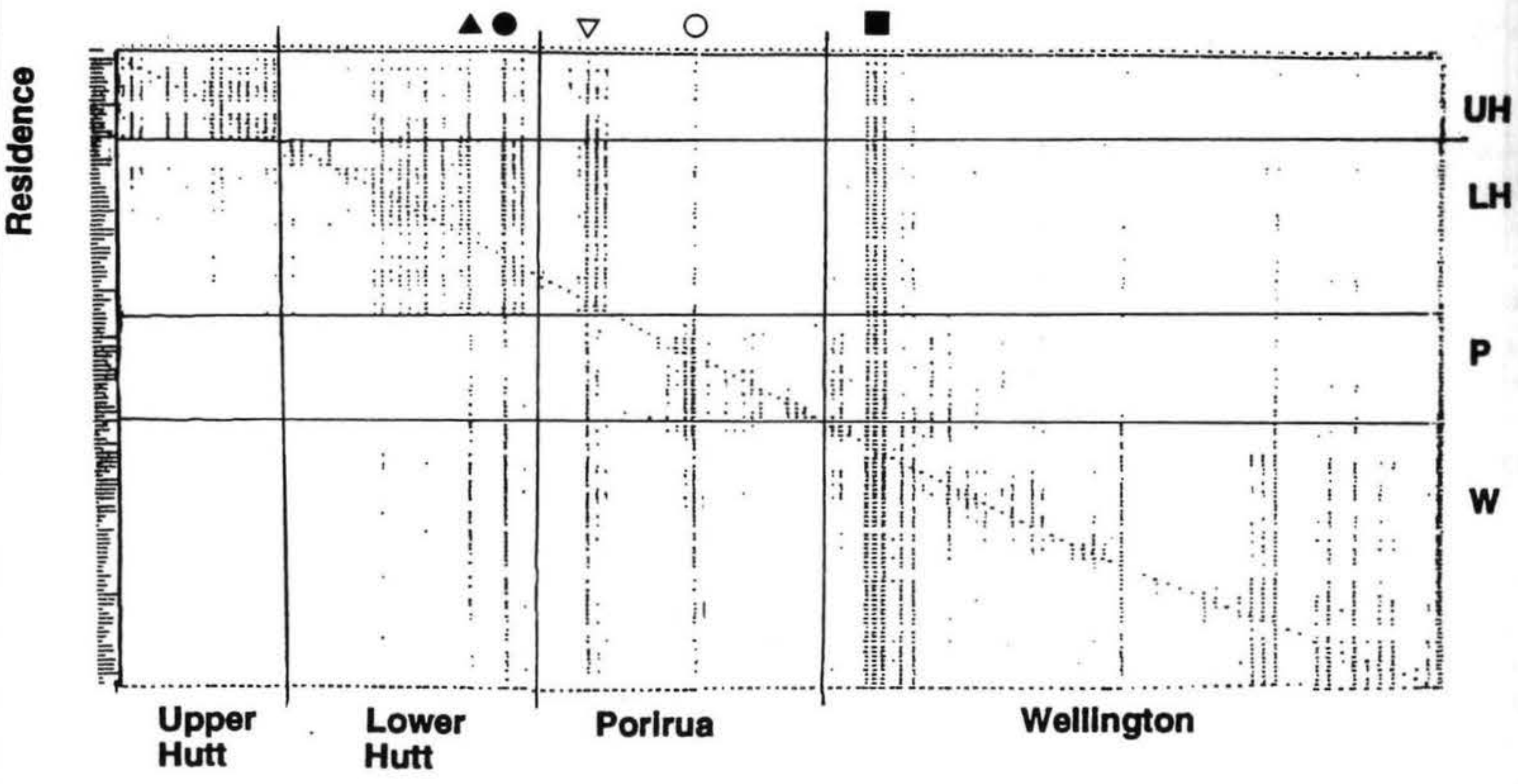

\section{Major workplaces}

Gracefield

Hutt Central

Petone Central $\quad \nabla$

Porirua Central

Thorndon-Tinakori Rd

Lambton Quay

Willis St-Cambridge Tce

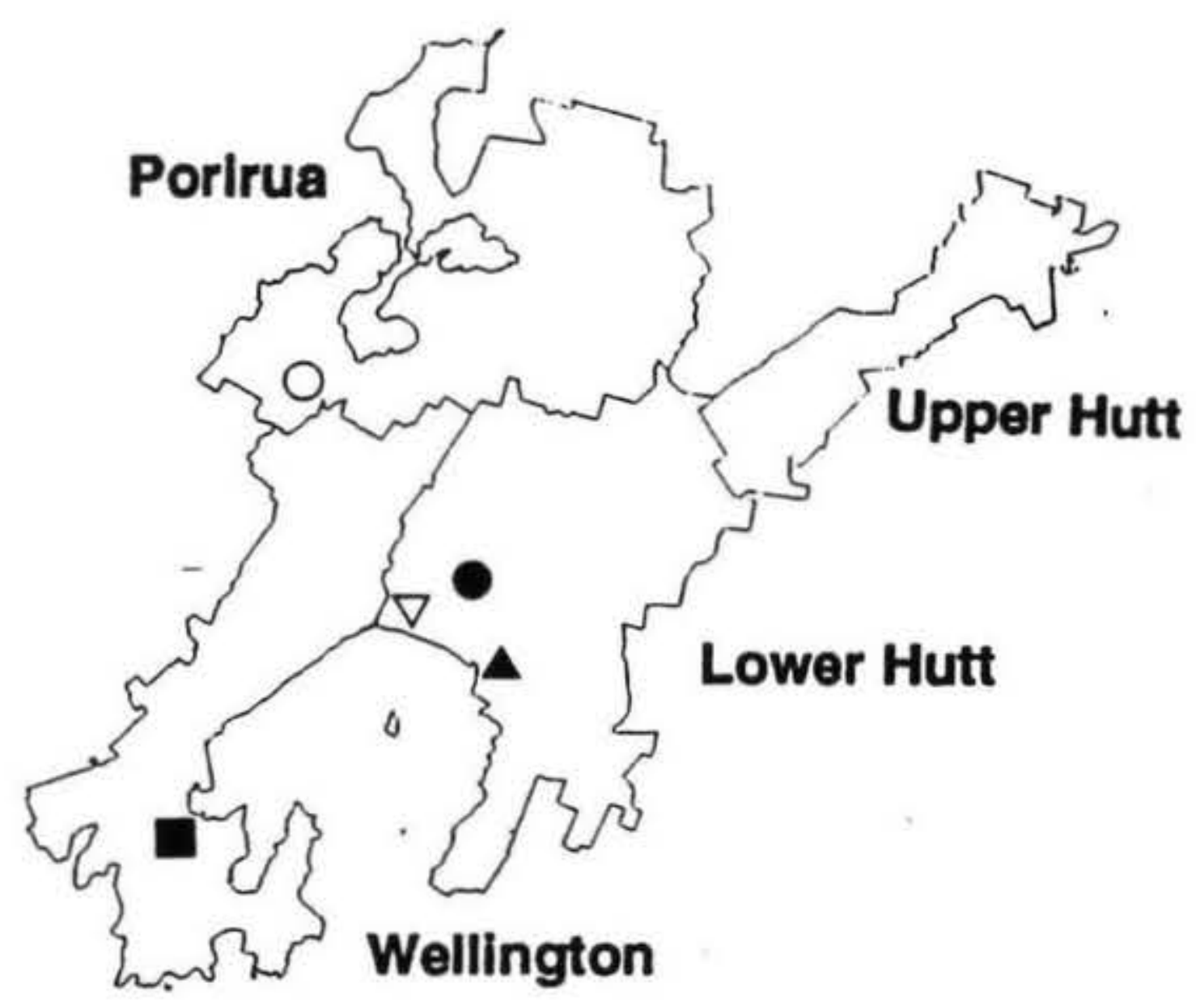

Source: Statistics New Zealand: SUPERMAP2 
urban area is partitioned into $i=j=n$ mutually exclusive area units. The table is permuted so the order of the places of residence (the rows) is the same as the order of the places of work (the columns). The sum over all areas of residence and areas of work $\Sigma \Sigma \mathrm{Eij}$, is the number of gainfully employed in the urban labour market (or at least of those who report both place of residence and work).

The journey to work matrix can be complicated when first encountered and one way of preparing for its detail is to examine the maps of the row and column totals. Figure 3 shows the two maps for the Wellington urban area, the distribution of the gainfully employed by workplace (column totals) and by usual residence (row totals).

A comparison of these two maps confirms that employment is much more concentrated spatially than residence even when the log of employment is used. The four main employment centres of employment stand out quite clearly as central Wellington to the south, Porirua to the northeast, Lower Hutt to the southeast and Upper Hutt to the northeast . (A guide to the area units is given in appendix 1).

These two maps are only an introduction however. What they do not show are the labour sheds of the various employment centres or the employment fields of those living in different parts of the region. Such information can only come from the matrix itself. At the same time it is not necessary to see the actual numbers of commuters in order to see the overall pattern. In fact in the heavily reduced version the matrix shown in figure 4 highlights more clearly the areal structure of the travel to work pattem within the Wellington urban area.
The term commuting is used loosely here to refer to all spatial connections between work and home, even those which only involve those working at home (see Loveridge, 1993). The reason is that the counts along the main diagonal combine those working at home with those commuting to work within the area unit in which they live. 10

One of the features of the Wellington case which emerges quite clearly from figure 4 is the highly localised nature of commuting. A substantial amount of commuting occurs between neighbouring area units. In none of the zones for example do more than 30 percent of the workers commute from outside their work zone; table 2 panel A. In this sense the employers face relatively self contained labour markets, particularly those in Upper Hutt which is the most distant from Wellington City. ${ }^{11}$

The relative self containment of the work places in the Wellington region does not mean that all those wanting jobs can obtain them locally of course for the number of jobs available differs markedly between the zones. Some areas are job rich, others are job-poor (Wachs et al, 1993: 1711). While job rich Wellington residents are fortunate in that over ninety percent of work is available within the zone in which they live (table 2, panel B), this is far from the case for job poor Porirua where 46.4 percent of residents have to commute to another zone to work. Lower Hutt is more self contained at 65.1 percent but Upper Hutt houses more than double the workers it provides work for (51.5\%). Although not documented here it is likely that, as in Melbourne there has been a steady rise in self containment, as local jobs have been filled by new local residents in expanding suburban areas (O'Conner, 1994:11). 12

Table 2. The residential and workplace distributions of the employed by zone in the Wellington Urban Area, 1991

\section{A. The percentage residential distribution of the employed in zones}

\begin{tabular}{lcccrr}
\hline Residence & Upper Hutt & $\begin{array}{c}\text { Workplace } \\
\text { Lower Hutt }\end{array}$ & Porirua & Wellington & Total \\
\hline Upper Hutt Zone & $\mathbf{8 2 . 3}$ & 10.6 & 1.9 & 3.8 & 10.5 \\
Lower Hutt Zone & 12.6 & $\mathbf{7 2 . 9}$ & 4.6 & 13.5 & 27.2 \\
Porirua Zone & 1.6 & 3.8 & $\mathbf{7 2 . 1}$ & 8.3 & 11.5 \\
Wellington Zone & 3.5 & 12.7 & 21.4 & $\mathbf{7 4 . 4}$ & 50.8 \\
Total & 100 & 100 & 100 & 100 & 100 \\
\hline
\end{tabular}

\section{B. The percentage residential distribution of the employed in zones}

\begin{tabular}{lccccr}
\hline Residence & Upper Hutt & $\begin{array}{c}\text { Workplace } \\
\text { Lower Hutt }\end{array}$ & Porirua & Wellington & Total \\
\hline Upper Hutt Zone & $\mathbf{5 1 . 5}$ & 24.7 & 1.3 & 22.5 & 100 \\
Lower Hutt Zone & 3.0 & $\mathbf{6 5 . 1}$ & 1.3 & 30.7 & 100 \\
Porirua Zone & 0.9 & 7.9 & $\mathbf{4 6 . 4}$ & 44.7 & 100 \\
Wellington Zone & 0.5 & 6.1 & 3.1 & $\mathbf{9 0 . 4}$ & 100 \\
Total & 6.5 & 24.3 & 7.4 & 61.8 & 100 \\
\hline
\end{tabular}


One of the arguments within the disintegration thesis advanced above was that not only were occupational groups separated residentially and some by the work place as well but that distinct, short journeys to work were also developing particularly in occupations that were being decentralised. The remaining step in this preliminary analysis is therefore to examine the work and residence location of one of the affected occupational groups, plant and machinery operators.

Figure 5. The distribution of fulltime plant and machine operators in the Wellington urban area by workplace and residence, 1991
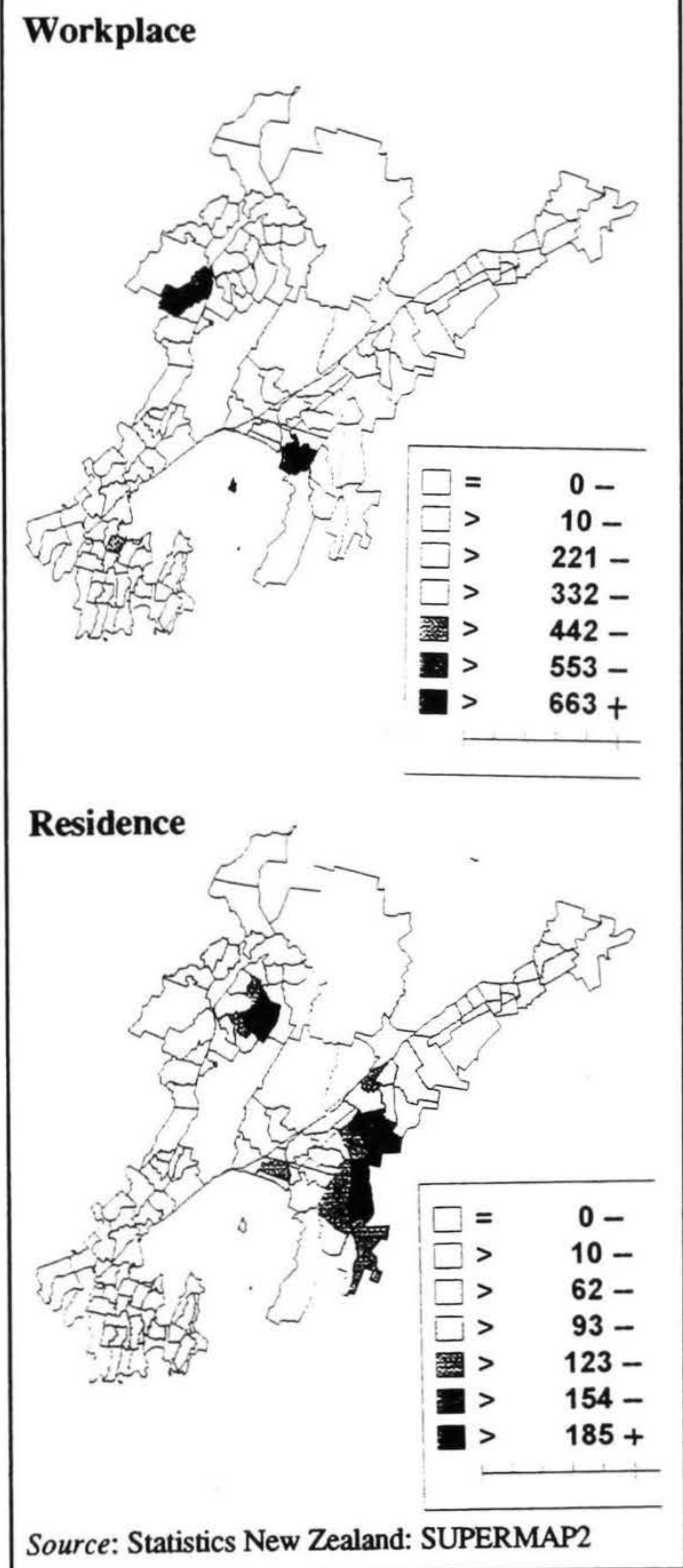

\section{Operators' work and residence}

Figure 5 shows the workplace and residence locations of the fulltime employed plant and machine operators in the three main centres of such employment - Porirua, Lower Hutt (Gracefield) and the central city. It is clear from these maps that plant and machinery operators reside quite closely to their major employment centres. 13

Figure 6. The distribution of part-time plant and machine operators in the Wellington urban area by workplace and residence, 1991

\section{Workplace}
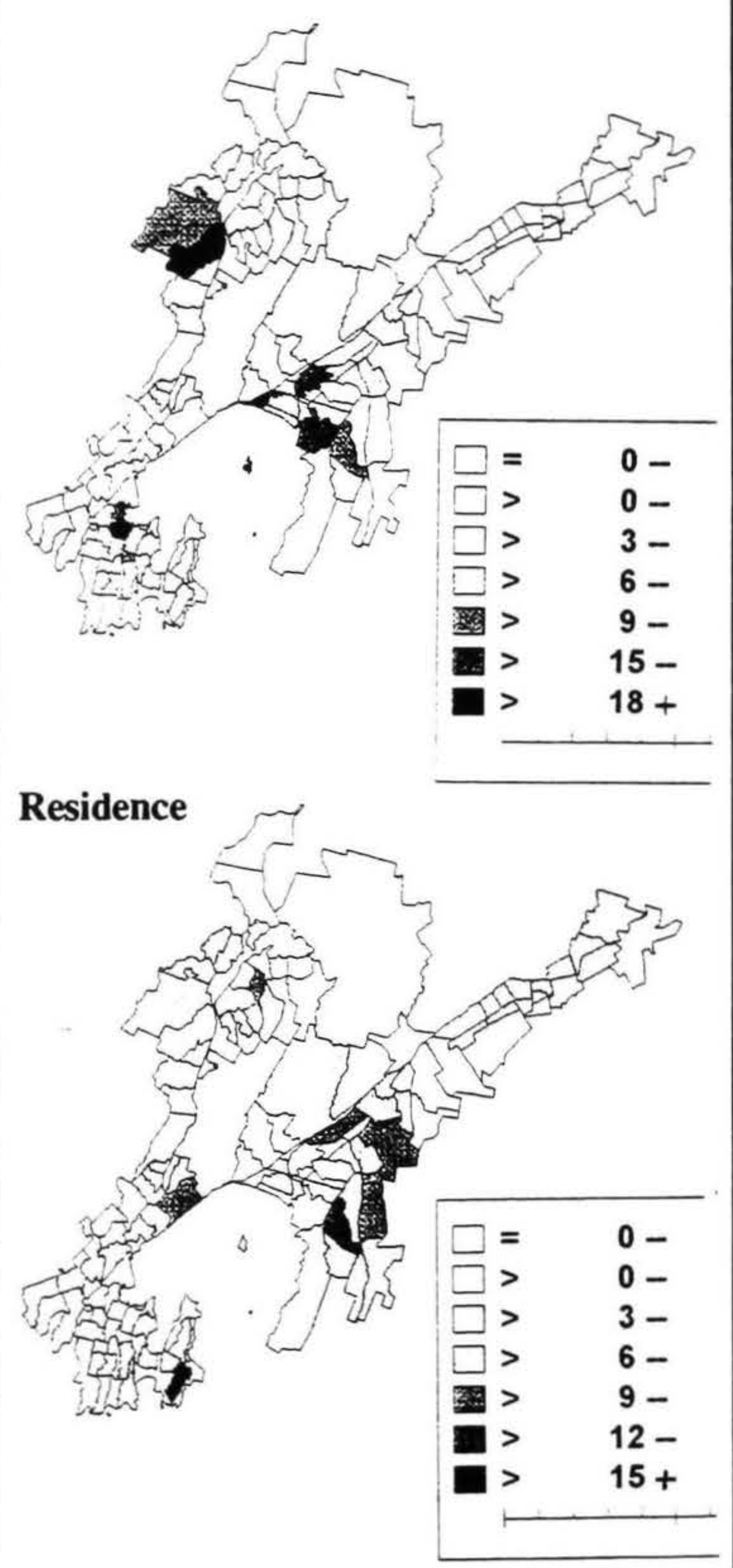

Source: Statistics New Zealand: SUPERMAP2 
A smaller proportion of machine operators are part-time workers and it appears from the maps in figure 6 that both their workplaces and residences are considerably more dispersed, a feature which corresponds with Loewenstain's observation about the wider catchment of marginal workers (1965). Part-time workers are likely to be secondary workers within the household and as such exercise less sway in residential location than their fulltime counterparts.
Exploring this last point a little further, a breakdown the map of full time workers by gender reveals subtle shifts in the pattern of commuting. Different industries and plant within this occupational category employ different types of plant and machine operators depending on whether they are male or female and the two maps in figure 7 reflect these differences.

The conclusion we draw from the evidence of this particular occupational group at least is that not only are the

Figure 7. The distribution of fulltime male and female plant and machine operators in the Wellington urban area by workplace and residence, 1991

\section{Male workplace}

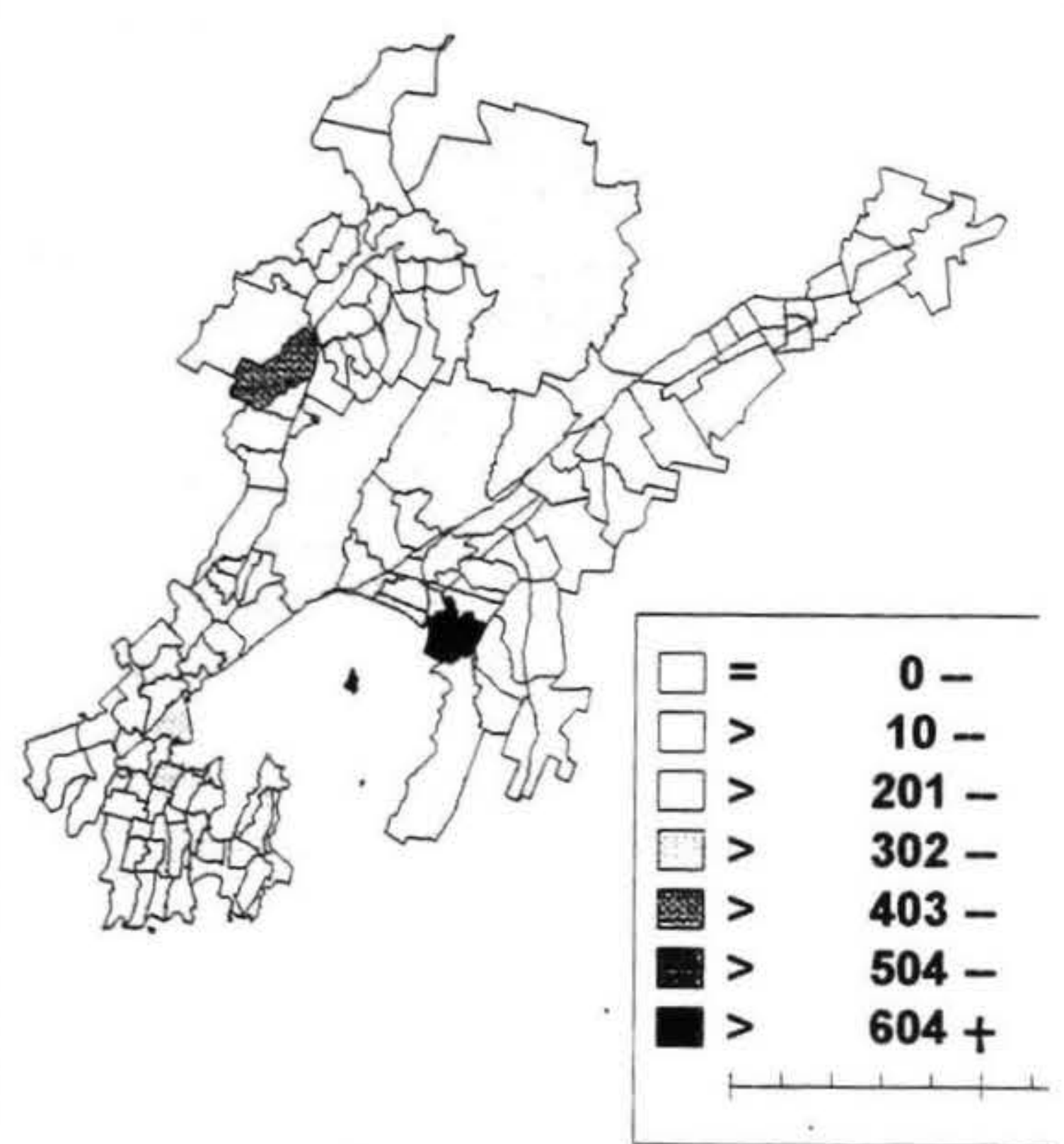

\section{Female workplace}

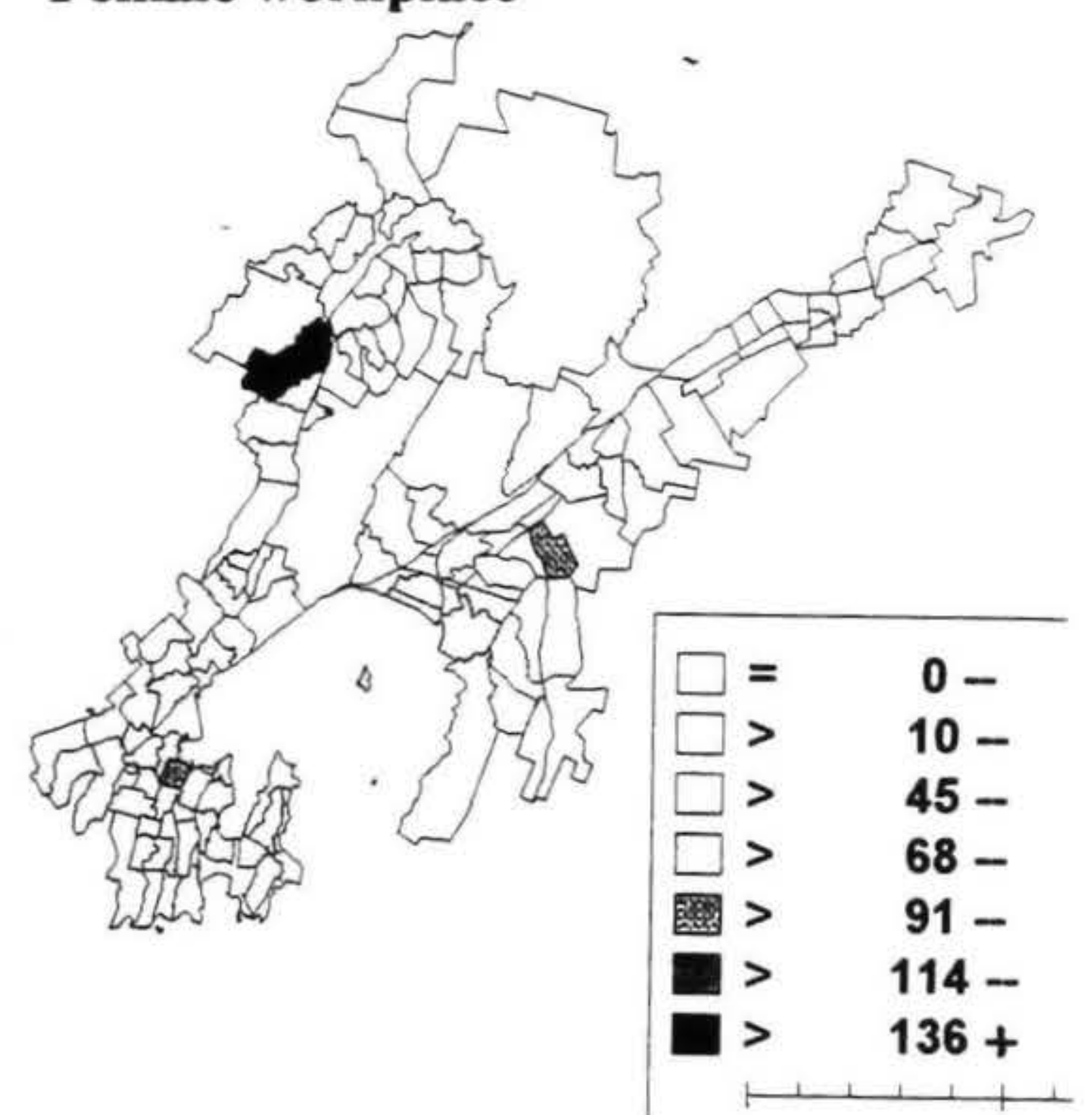

Male residence

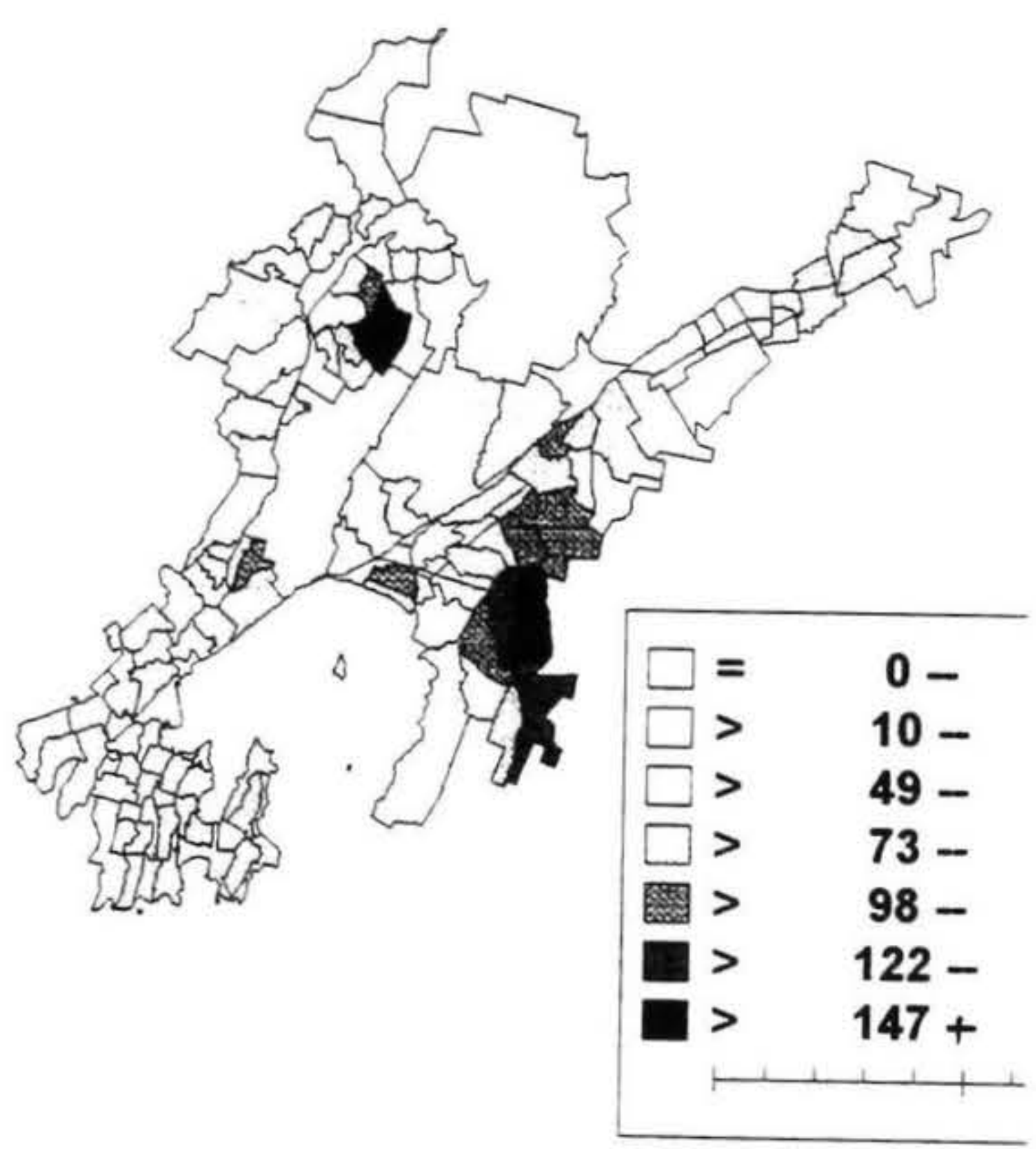

Female residence

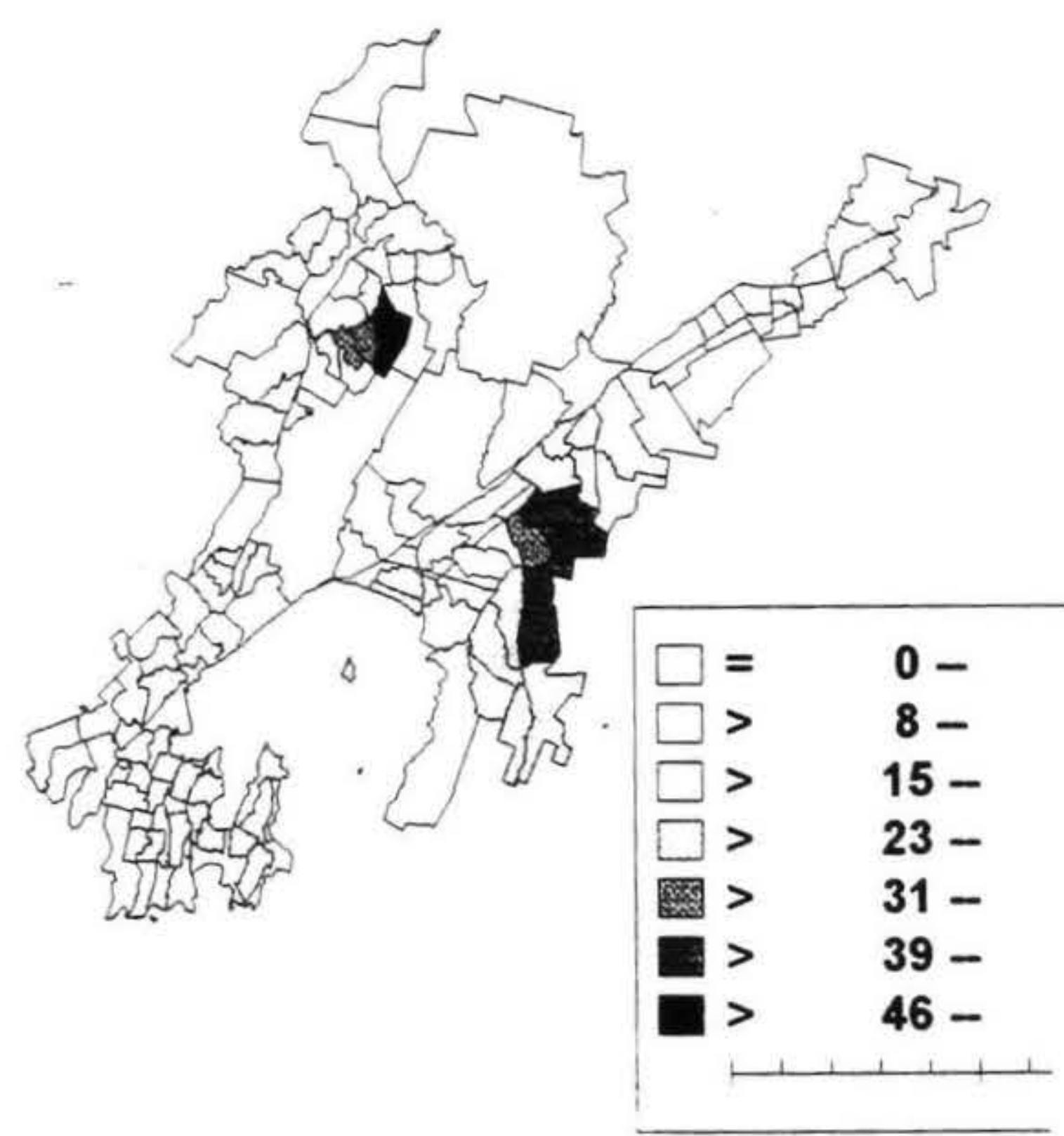

Source: Statistics New Zealand: SUPERMAP2 
places of work clustered and distinct geographically, but so too are their proximate places of residence. It follows that commuting patterns too would be distinct. What is also apparent however is that contractual attachment to the place of work (as in fulltime vs part-time) and gender divisions of labour within the main industries of these occupations also have an impact on the way in which the labour market for such tasks are spatially organised.

In short, the evidence presented is consistent with the disintegration thesis although for one occupational group only. What makes this occupational group particularly relevant however is their vulnerability to the restructuring of the manufacturing industry and the way in which job losses in factories left many such workers in job deficient areas. Although lowering commuting and housing costs historically, decentralisation had the effect of rendering urban factory workers in particular that much more vulnerable to structural change. This vulnerability operated not only through their income but also their housing assets whose value was depreciated because of the economic shadow that declining of employment cast over the labour catchments of manufacturing sites in the 1980 s and early 1990s.

\section{Conclusion}

There are three dimensions to the work-residence relationship. The first is the presence of occupational separation both by residence and in some occupations at least by workplace. The second is the distance decay property of labour catchments whose parameters are quite sensitive to gender, whether part or full time work is involved and to income. The third strand is the physical siting of employment in relation to residence, the resultant journey to work and the way in which this reduces or exacerbates the segregative properties implied by the first two dimensions.

It has been my argument that these three strands are worth exploring both individually and collectively in order to empirically test the disintegration thesis. The evidence presented here is no more than exploratory of course. All we can say at this stage in the research is that the experience of plant and assembly workers in the Wellington region is worth exploring further to see if their experience over time is consistent with the thesis and increasing spatial clustering of jobs and residence

The empirical beginnings offered in this paper rely on the Census of Population and Dwellings and there is considerable scope for using these data over time to explore the disintegration thesis in a variety of settings. One of the advantages is that the analysis is replicable via the census for other New Zealand (and Australian) cities. One of the challenges now is to develop a test of the suggested link between structural change (the shift in the mix of industries and occupations within them) and the (further) disintegration of the city as a social unit.
Suffice it at this stage to state my own expectation which is that structural change will bring about further separation of occupational based socio-economic divisions both at home and at work and that this can be expected in several cases to be reinforced by increasingly separate journeys to work. Lying behind this concem over the link between the geography of the urban labour market, structural change and disintegration is the growing link between 'internationalisation and restructuring' (see Clark and KnipersLind, 1994). Out of this last linkage in particular should come clues as to the next likely stage in the development of our urban areas as expressions of the organisation of local labour markets tied as they are to trends in the global organisation of capital.

\section{Future research}

While an argument has been advanced in this paper, the necessary empirical work has been limited to a quite preliminary exploration of the geography of residence and work in one city, and while some provocative patterns were identified the more detailed investigation was confined to plant and machinery operators and even then work-residence connections were imputed from their locations rather than demonstrated via a journey to work matrix specific to their occupation.

If the disintegration thesis is to be explored more fully then the journey to work matrix will have to be dissaggregated by occupation. This would be valuable exercise but the special runs by Statistics New Zealand would require funding. But that alone would not provide an adequate data base to test the thesis. Any adequate test of the relationship between structural change and the new occupational classification that was introduced in 1991 must await comparison with the 1996 census. Such data would allow the direction of spatial clustering implicit in the disintegration thesis to be tested explicitly. Then of course we would want to move beyond the single city study to look at evidence for the same processes operating in Auckland and Christchurch at least. Comparisons with well documented patterns overseas could then begin which should enrich our understanding of the processes which link structural change to the geographical properties of the urban labour market.

\section{References}

Barnett, J. R. 1987 Privatising hospital care in New Zealand: curse or blessing New Zealand Geographer 43 (3): $155-164$

Barnett, J.R. 1993 Does the geographic distribution of physicians reflect market failure?: an examination of the New Zealand experience, 1981-1987 Environment and Planning A 25(6): 827-846

Black, A. 1990 Analysis of census data on walking to work and working at home Transportation Quarterly XLIV 107-121 
Blumen, O. and A. Kellerman 1990 Gender differences in commuting distance, residence and employment location. Metropolitan Hiafa 1972-1983 Professional Geographer 42: 54-71

Boyle, P.J. and R. Flowerdew 1993 Modelling sparse interaction matrices: interward migration in Hereford and Worchester, and the underdispersion problem Environment and Planning A 25(1201-1209

Brown, L.A. and J. Holmes 1971 The delimitation of functional regions, nodal regions, and hierarchies by functional distance apparoaches Journal of Regional Science 11(1): 57-72

Carroll, J.D. 1952 The relation of homes to work places and the spatial pattern of cities Social Forces 30: 271-283

Ceramalus, N. 1994 Think computing, not commuting Management August 110-111

Clark, W.A.V. and M. Kuipers-Linde 1994 Commuting in restructuring urban regions Urban Studies 31 ( ): $465-483$

Dahms, F.A. 1973 Work-place residence linkages in Auckland, 1963. In R.J. Johnston (ed.) Urbanisation in New Zealand. Geographical essays Reed Education: $235-254$

Davies, S. and M. Albaum 1972 Mobility problems of the poor in Indianapolis. In R. Peet (ed.) Geographical perspectives on American poverty Worchester, Mass.: Antipode Monographs in Social Geography. Cited in King and Colledge (my copy)

Duncan, B. 1956 Factors in work-residence separation: wage and salary workers, Chicago 1951 American Sociological Review, 21 (Feb): 48-56

Duncan, O.D. and B. Duncan 1955 Residential distribution and occupational stratification American Journal of Sociology 60: 493-503

Feinstein, S., Gordan, I. and M. Harloe 1992 Divided Cities Oxford: Basil Blackwell

Giuliano, G. and K.A.Small 1993 Is the journey to work explained by urban structure? Urban Stuides 30(9): 1485-1500

Goldner, W. 1955 Spatial and locational aspects of metropolitan labour markets American Economic Review 45(1): 113-128

Goldstein, S. and K. Mayer 1964 Migration and social status differentials in the journey-to-work Rural Sociology 29 (Sept) : 278-287
Gordon, P. and A. Kumar and H. Richardson 1989 The influence of metropolitan spatial structure on commuting time Journal of Urban Economics 26: 138151

Guest, A.M. 1976 Night-time and daytime populations of large American suburbs Urban Affairs Quarterly 12(1): $57-82$

Hamnett, C. 1994 Social polarisation in global cities: theory and evidence Urban Studies 31(3): 401-424

Hanson, S and G. Pratt 1991 Job search and the occupational segregation of women Annals of the Association of American Geographer s 81(2): 229253

Hasluck, C. 1987 Urban unemployment. Local labour markets and employment initiatives New York, Longman

Higano, Y. and I. Orishimo 1990 Impact of spatially separated work places on urban residential location, consumption and time allocation Papers of the Regional Science Association 68: 9-21

Holti, R. and E. Stern 1986 Distance working Tavistock Institute. Commission of the European Communities-FAST programme

Houghton, S. 1988 Income differentials and housing costs in cities and suburban areas Urban Policy and Research 6: 161-180

Jones, M.E. 1972 Settlement patterns of occupational groups. An Upper Hutt study Town Planning Quarterly 25: 26-29

Kain, J. F. and J. R. Meyer 1976 Transportation and poverty. In Hochman, H.M. (ed.) The urban economy New York: W.W. Norton \& Company Inc

Kain, J.F. 1962 The journey-to-work as a determinant of residential location Papers and Proceedings of the Regional Science Association 9: 137-160

Langdon. P. 1994 A better place to live: reshaping the American suburb University of Massachusetts Press

Lauder, H. et al 1994 The creation of market competition for education in New Zealand. An empirical analysis of a New Zealand secondary school market, 19901993 The Smithfiled Project Phase One First Report to the Ministry of Education, March.

Le Grand, J and R. Robinson (eds) Privatisation and the welfare state London: George Allen and Unwin

Liepmann, Kate K. 1944 The journey to work New York: Oxford University Press 
Loewenstain, L.K. 1965 Residences and work places in urban areas New York: The Scarecrow Press

Loveridge, A. 1993 Who works at home? In Morrison, P.S. (ed.) Labour, employment and work in New Zealand. Proceedings of the Fifth Conference, Nov 12-13 1992, Victoria University of Wellington

McGee, T.G. 1969 The social ecology ofNew Zealand cities. A preliminary investigation. In John Forster (ed.) Social process in New Zealand. Readings in Sociology. Longman Paul

Maher, C.J. Whitelaw, A. McAllister, R. Francis, J. Palmer, E. Chee and P. Taylor 1992 Mobility and locational disadvantage within Australian cities: social justice implications of household relocation Canberra: Australian Government Publishing Service

Marcuse, P. 1989 Dual city: a muddy metapher for a quartered city. International Journal of Urban and Regional Studies 13(4): 697-708

Massey, D.and R.Meegan 1982 The anatomy of job loss. The how, why and where of employment decline London: Methuen

Mayhew, K. 1977 Eamings dispersion in local labour markets: implications for search behaviour $O x f o r d$ Bulletin of Economics and Statistics 39(2): 93-107

Morrison, P.S. 1989 Labour adjustment in metropolitan regions VUW Press for Institute of Policy Studies

Morrison, P.S. 1990 Segmentation theory applied to local, regional and spatial labour markets Progress in Human Geography 14(4): 488-528

Morrison, P.S. 1993a Using SUPERMAP2 for policy analysis. Geographic implications of recent housing reforms New Zealand Population Review 19(1 \& 2): $32-64$

Morrison, P.S. 1993b Income inequalities within the city and the privatisation of urban services. An application of SUPERMAP2 Proceedings of the Seventheenth New Zealand Geographical Society Conference, September 1993: 489-499.

Morrison, P.S. 1995 The geography of rental housing and the restructuring of housing assistance in New Zealand Housing Studies 10(1):39-56

Nelson, K. 1986 Labour demand, labor supply and the suburbanisation of low-wage office work. Chapter 8 in A.J. Scott and M. Storper (eds) Production, work and territory Allen and Unwin: 149-171

Newman, P. and J. Kenworthy 1989 Gasoline consump- tion in cities: a comparison of U.S. cities with a global survey Journal of the American Planning Association 55(1): 24-37

O'Conner, K and C. A. Maher 1982 InL.S. Bourne (ed.) Internal structure of the city New York: Oxford University Press 406-421 Reprinted in modified form from Regional Studies vol 131979 pp. 361-380

O'Conner, K. 1994 Getting to work: thirty years of travel in Melbourne. Department of Geography and Environmental Science Monash University, Prepared for Transport Policy Lecture Series, August. Typscript

\section{OECD 1994 School: a matter of choice OECD}

Pinch, S. 1993 Social polarization: a comparison of evidence from Britain and the United States Environment and Planning A, 25(6): 779-796

Rees, A. and G.P. Schultz 1970 Workers and wages in an urban labor market Chicago: Chicago University Press

Sassen, S. 1991 The global city: New York, London, Tokyo Princeton: Princeton University Press

Schnore, L. F. 1965 The urban scene. Human ecology and demography Toronto: The Free Press

Smart, M.W. 1974 Labour market areas: uses and definition Progress in Planning 2(4): 252-260

Stanback, T.M. 1991 The new suburbanisation: challenge to the central city. Westview Press

Stubbs, J. and J. Barnett 1992 The geographically uneven development of privatisation: towards a theoretical approach Environment and Planning A 24: $117-135$

Vance, J. E. 1971 Land assignment in pre-capitalist, capitalist and post-capitalist cities Economic Geography 47: 101-120

Wachs, M. B.D. Taylor, N. Levine and P. Ong 1993 The changing commute: a case study of the job hunting relationship over time Urban Studies 30( ): 1911-1789

Wheeler, J.O. 1967 Occupational status and work-trips: a minimum distance approach Social Forces 45 (June) : 508-515

Wheeler, J.O. 1968 Residential location by occupational status Urban Studies 5(1). Reprinted in L.S. Bourne 1971 Internal structure of the city. New York: Oxford University Press: 309-315 
White, Michelle J. 1994 Housing and the journey to work in U.S. cities Yukio Noguchi and James M. Poterba Housing markets in the United States and Japan National Bureau of Economic Research pp 133-159

Wilkinson, L, M. Hill and E. Vang 1992 SYSTAT for the Macintosh, Version 5.2 SYSTAT, Inc., Evanston, Illinois.

Winchester, H. and M, J. White 1988 Location of marginalised groups in the inner city Environment and Planning D Society and Space 6: 37-54

Wolforth, J. 1965 The journey to work British Columbia Geography Series No 4 240-247

\section{Notes}

1 This paper forms part of a wider FRST funded project examining the employment consequences of structural change. It extends the author's earlier work on the differential impact of structural change in the 1970s and 1980s on the four main metropolitan labour markets (see Morrison, 1989).

2 The New Zealand Standard Classification of Occupations was revised in 1990. It now lists 10 major occupational groups which are defined in terms of skill requirement rather than type of work performed as with previous censuses. This means that occupation is more closely aligned with education differences, income and social prestige.

3 Counts in each area unit are downloaded from SUPERMAP2 via EXCEL output from which is then which is imported by the statistical package SYSTAT. For details of SYSTAT see L. Wilkinson, M. Hill and E.Vang (1992).

4 A logical extension of this analysis would be to examine the extent to which we are conflating occupations with different gender mixes. However this was not the case. Preliminary exploration suggests that splitting the population by gender actually weakens the quantitative picture of occupational segregation by residence.

${ }^{5}$ There was also at this time a recognition that certain parts of a population were being disadvantages by these shifts. John Kain and Meyer for example noted how the central city poor are disadvantaged in gaining access to jobs which are increasingly suburban jobs initially because of reliance on public transport, and then, if a car is purchased by longer commuting distances (Kain and Meyer, 1976). The same lack of accessibility to clerical and manufacturing jobs for those dependent on public transit was documented by Davies and Albaum, (1972).

6 In their discussion of restructuring of local US economies Clark and Kuipers-Linde refer to both residents and employers having great degree of locational flexibility and development of a less hierarchical and more localistic conception of space (1994: 467). This greater flexibility in turn provides an opportunity for local industry to restructure its operations. What results is a movement of jobs within the urban area, from one set of residents to another. The scale is different but there are interesting parallels here between this intra-metropolitan process and the concerns of those who write on global cities, those whose economic base has also been altered by the changing international division of labour (see Feinstein et, al 1992 and Sasson, 1991).

7 This does not always mean a reduction in costs of travel and recent attention is being paid to the most efficient way of spatially arranging places of work and residence (see Guiliano and Small, 1993). In 1984 for example, Los Angeles drivers spent an average of 215,000 hours a day stuck in traffic (Wachs et al, 1993: 1713).

8 Schnore goes on to demonstrate a relationship between workshift and distance travelled to work. Those with least accumulated seniority were most often assigned the afternoon and evening shifts and these workers travelled longer distances. This lead Schnore to observe how the marginal labour force may also be physically marginal to a given industrial community (Schnore 1965: 335-6). The need to also maintain other job connections such as part-time farming while responding to the temporary demands of the volatile automobile industry were discussed as possible reasons for this. Ride sharing also increased as a way of minimizing the costs of those who were not demonstrating the least effort principle by residing close to the plant being studied.

9 Not all the gainfully employed respondents have fixed workplaces (or usual residences for that matter) and those that do can fail to supply usable information. Australian and New Zealand coverage of the journeys to work are between 80 and 90 percent.

10 The need to incorporate and assess the theoretical implications of the increasing number working at home (including teleworkers) into traditional residential location models is discussed by Higano and Orishmo (1990).

11. The average (straight line) distance between any two area units is only about 7 kilometres, a figure which can be calculated directly via pythagoras from the centroids of the area units weighting each estimated distance by the number of commuters.

${ }^{12}$ Notwithstanding the fact that some areas in most metropolitan centres will have experienced markedly different rates of growth in jobs and population and that while self containment will have increased in some, in others residents will find jobs per resident decreasing.

13 As Gordon, Kumar and Richardson (1989: 150) have observed, clustered manufacturing activities in a decen- 
tralised employment centre provide a spatial structure condusive to residential site choices with shorter commuting although, as Dahms has observed (1973:243) for Auckland and is true of Wellington too, many workers in the 1960s took advantage of generous government assistance to build or rent accommodation in the post-war suburbs near to their place of employment. Note incidentally that we are assuming that workers live in proximate residential areas, e.g. that those working in Lower Hutt also live there. A journey to work matrix would have to be assembled for this occupationaly group to test that assumption.

\section{Author}

Philip Morrison is a Senior Lecturer in Geography, Victoria University of Wellington, PO Box 600 , Wellington.

\section{Appendix 1: Wellington Urban Area. Area Units, 1991 census}

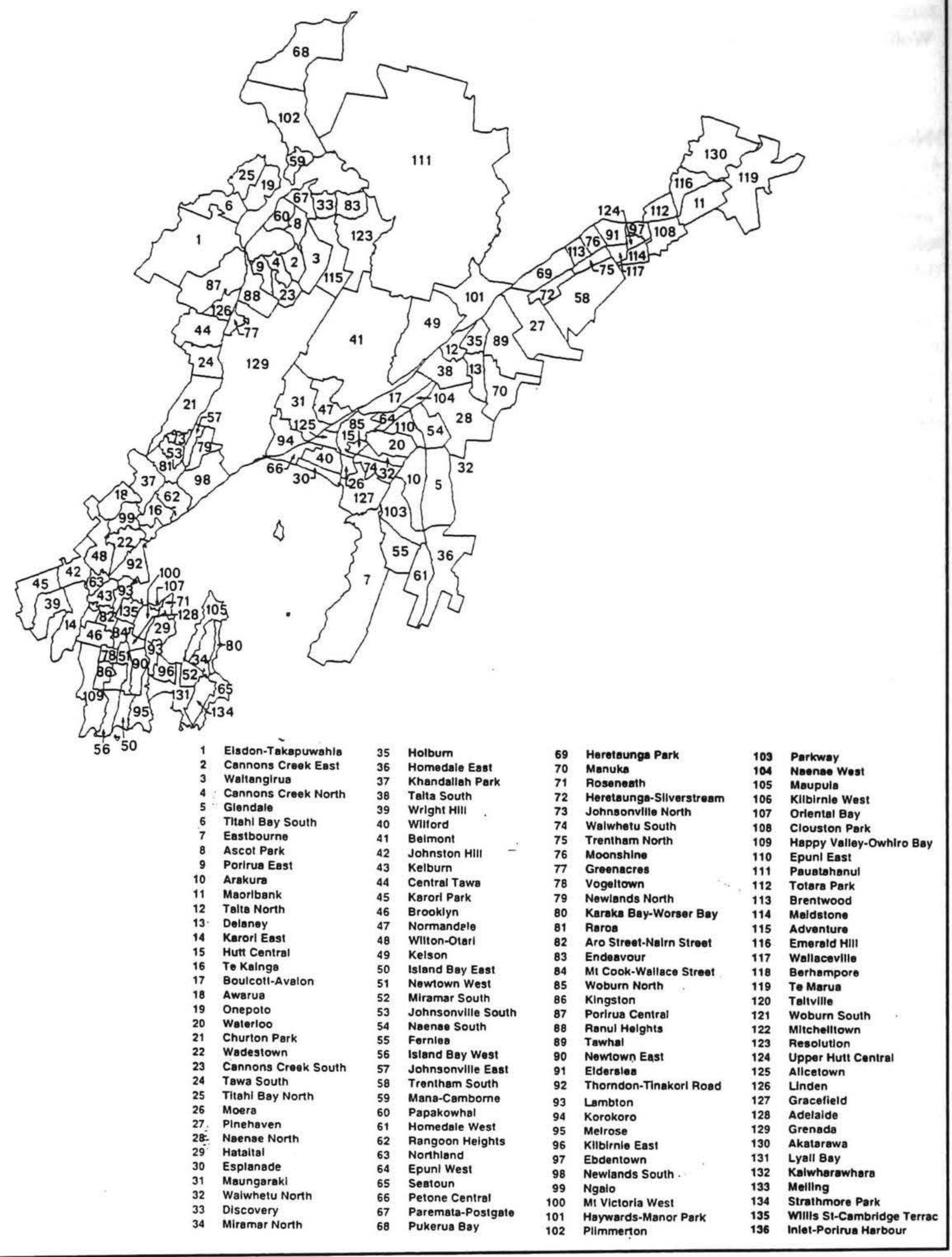

